\title{
PENGARUH PEMBERIAN AJUVAN ASAM FOLAT TERHADAP FUNGSI PERSONAL DAN SOSIAL PASIEN SKIZOFRENIA KRONIK
}

\author{
Rini Suprapti $^{1 *}$, Alifiati Fitrikasari ${ }^{1}$, Rihadini $^{2}$, Hang Gunawan Asikin ${ }^{1}$, Elly Noerhidajati $^{1}$ \\ ${ }^{1}$ Bagian Psikiatri, Fakultas Kedokteran, Universitas Diponegoro, Kompleks Dekanat Lama Lt 1 FK Undip Jl. dr. Sutomo No.16, Randusari, Kec. \\ Semarang Selatan, Kota Semarang, Jawa Tengah, 50244, Indonesia. \\ ${ }^{2}$ RSJD dr. Amino Gondohutomo Provinsi Jawa Tengah, Jl. Brigjend. Sudiarto no 347, Gemah, Kec. Pedurungan, Kota Semarang, Jawa Tengah \\ 50611, Indonesia \\ *Korespondensi : E-mail: riniafee18@gmail.com
}

\begin{abstract}
Background: The results of schizophenia treatment showed that as many as $85 \%$ patients had decreased function. Clinical remission does not always lead to restoration of function. Folate deficiency has been identified as a risk factor for schizophrenia.

Objective: To determine the benefits of folic acid supplementation in improving the personal and social functions of chronic schizophrenia patients.

Methods: This was an Experimental study with double blind - randomized controlled trial design, pre post test design. All subjects who met the inclusion criteria were taken according to time (consecutive sampling), then randomly grouped into the treatment group and the control group. Treatment group received anti psychotic with folic acid adjuvant $2 \mathrm{mg} /$ day for 4 weeks. Control group received anti psychotic with placebo. The antipsychotic used was not the same. Both the treatment group and the control group used various anti-psychotics. PSP (Personal and Social Performance) was measured before and after treatment. The research instrument consisted of a sociodemographic questionnaire and a structured interview questionnaire and the Indonesian version of the Personal and Social Performance Scale.

Results: There were 66 subjects who met the inclusion criteria, 2 of them dropped out due to seizures and Malignant Neuroleptic Syndrome. There was no significant difference in the comparative test of demographic characteristics of the treatment group and the control group. There was an increase in PSP score which was statistically significant $p<0.01$ in both groups with a higher increase in PSP score in the treatment group $p=0.029$.
\end{abstract}

Conclusion: Folic acid supplementation improves personal and social performance of chronic schizophrenia patients.

Keywords : Chronic schizophrenia; Folic acid adjuvant; Personal and social performance.

\begin{abstract}
ABSTRAK
Latar Belakang : Hasil pengobatan skizofenia menunjukkan sebanyak 85\% mengalami penurunan fungsi. Remisi klinis tidak selalu mengarah pada pemulihan fungsi. Defisiensi folat diidentifikasi sebagai salah satu faktor risiko skizofrenia. Tujuan : Mengetahui manfaat ajuvan asam folat dalam memperbaiki fungsi personal dan sosial pasien skizofrenia kronis. Metode : Penelitian eksperimental dengan desain double blind - randomized controlled trial, pre post test design. Semua subjek yang memenuhi kriteria inklusi diambil menurut waktu (consecutive sampling), kemudian secara blok random dikelompokkan dalam kelompok perlakuan dan kelompok kontrol. Perlakuan dengan ajuvan asam folat $2 \mathrm{mg} / \mathrm{hari}$ selama 4 minggu. Kelompok kontrol mendapatkan anti psikotik dengan plasebo. Anti psikotik yang digunakan tidak sama. PSP diukur sebelum dan sesudah perlakuan. Instrumen penelitian menggunakan kuesioner sosiodemografi dan kuesioner wawancara terstruktur Personal and Social Performance Scale versi Indonesia.

Hasil : Terdapat 66 subjek yang memenuhi kriteria inklusi, 2 diantaranya Drop Out karena kejang dan SNM. Uji komparatif karakteristik demografik kelompok perlakuan dan kelompok kontrol tidak ada perbedaan bermakna. Terdapat peningkatan skor PSP yang bermakna secara statistik $\mathrm{p}<0,01$ di kedua kelompok dengan peningkatan skor PSP kelompok perlakuan lebih tinggi $(\mathrm{p}=0,029)$.
\end{abstract}

Simpulan : Ajuvan asam folat memperbaiki fungsi sosial dan personal pasien skizofrenia kronis.

Kata Kunci : Ajuvan asam folat; Fungsi sosial dan personal; Skizofrenia kronis. 


\section{PENDAHULUAN}

Skizofrenia adalah gangguan mental berat, kronik dan melemahkan yang mempengaruhi $1 \%$ populasi dunia. ${ }^{1}$ Skizofrenia merupakan penyebab utama nomor tiga disabilitas individu dibawah usia 45 tahun. Hasil pengobatan saat ini menunjukkan $85 \%$ pasien mengalami penurunan derajat fungsi, dan diketahui bahwa remisi klinis tidak selalu mengarah pada pemulihan fungsi. ${ }^{2}$ Skizofrenia berada dalam siklus remisi dan relaps, mengakibatkan beban keuangan dan humanistik pada masyarakat. ${ }^{3}$

Global Burden Diseases (GBD) tahun 2016 menyatakan skizofrenia sebagai kontributor utama beban penyakit. ${ }^{2}$ Riset Kesehatan Dasar (Riskesdas) Kementerian Kesehatan RI tahun 2018 melaporkan prevalensi keluarga yang mempunyai anggota keluarga skizofrenia atau psikosis sebesar 7 per mil, angka ini naik dari hasil Riskesdas tahun 2013 yaitu sebesar 1,7 per mil. WHO menetapkan bahwa proporsi gangguan mental dalam suatu populasi maksimal sebesar 10\%. Data Riskesdas tersebut menjadi landasan yang cukup kuat untuk meningkatkan kepedulian pada kesehatan mental. ${ }^{4}$

Penelitian asam folat pada skizofrenia menunjukkan bahwa defisiensi asam folat diidentifikasi sebagai salah satu faktor risiko skizofrenia. ${ }^{5}$ Folat berperan mengurangi Reactive Oxygen Species (ROS) melalui mekanisme upregulasi protein penyerap ROS dan mencegah pengurangan glutathione mitokondria melalui pemeliharaan homeostasis redoks. ${ }^{6}$ Penelitian sebelumnya menggunakan asam folat $2 \mathrm{mg}$ dan 400 mcg vitamin B12 selama 16 minggu pada pasien skizofrenia fase stabil dirawat jalan.

Berdasarkan pemahaman bahwa pada skizofrenia kronik terjadi proses stres oksidatif dimana ROS berlebih dibandingkan dengan individu non skizofrenia, sementara diketahui folat diperlukan dalam mengurangi ROS sebagai regulator redoks. Defisiensi folat diketahui sebagai faktor risiko skizofrenia. Kronisitas skizofrenia berpengaruh pada fungsi sosial. Fungsi personal dan sosial meliputi empat domain meliputi perawatan diri, aktivitas yang berguna secara sosial, hubungan personal dan sosial serta perilaku agresif / permusuhan. Dengan penelitian ini peneliti ingin mengetahui manfaat ajuvan asam folat dalam memperbaiki fungsi personal dan sosial pasien skizofrenia kronis, mengetahui karakteristik demografi pasien yang dirawat serta apakah terdapat perbedaan skor PSP (Personal and Social
Performance Scale) kelompok perlakuan dibanding kontrol.

\section{METODE}

Merupakan penelitian eksperimental dengan desain penelitian double blind - randomized controlled trial, pre and post test design. Penelitian dilaksanakan antara 1 Juli hingga 30 Agustus 2020. Populasi terjangkau adalah pasien skizofrenia kronik yang dirawat di RSJD dr. Amino Gondohutomo Semarang pada periode penelitian. Subjek penelitian meliputi pasien skizofrenia rawat inap dengan lama sakit minimal 2 tahun $^{7}$, mendapat pengobatan psikotropika dengan atau tanpa tambahan anti kolinergik, usia 20 - 50 tahun, minimal lulus SD dan keluarga memberikan consent penelitian. Kriteria eksklusi jika memiliki gangguan medik umum dan atau komorbid lain, terdapat riwayat penggunaan zat dan alkohol yang diketahui dari wawancara dan memakai obat anti epilepsi. Subjek dikategorikan drop out jika menunjukkan efek samping pemberian ajuvan atau mengalami gejala klinis yang memberat selama pengobatan.

Semua subjek yang memenuhi kriteria inklusi semua diambil sebagai sampel. Kemudian dilakukan randomisasi secara blok, dengan besar blok 4 untuk menetukan kelompok perlakuan dan kelompok kontrol. Besar sampel minimal dengan koreksi drop out $10 \%$ sebanyak 33 subjek/ kelompok. Variabel bebas asam folat dan variabel tergantung fungsi sosial dan personal. PSP diukur sebelum dan sesudah perlakuan oleh peneliti. Instrumen penelitian menggunakan kuesioner sosiodemografi dan kuesioner wawancara terstruktur Personal and Social Performance Scale (PSP) versi Indonesia yang dinilai oleh peneliti. Penilaian fungsi sosial dengan PSP terdiri dari 4 domain penilaian yaitu : perawatan diri, hubungan / interaksi sosial, aktivitas yang berguna secara sosial, dan perilaku agresif dan mengganggu (Tabel 1). Setiap domain dinilai keparahan hendaya (disabilitasnya) menjadi 6 kelompok yaitu tidak ada, ringan, terlihat, nyata/ jelas, berat dan sangat berat. Tiap domain dinilai dan dijumlah. Penilaian fungsi personal dan sosial dalam interval 10 dari 1 (disfungsi maksimal) sampai 100 (berfungsi maksimal). Total skor melebihi 70 mengindikasikan suatu kondisi remisi fungsional, dengan skor yang terkait dengan keseluruhan fungsi yang baik. Penilaian fungsi sosial dan personal dapat dibagi menjadi : skor $\geq 70$ : menunjukkan fungsi yang tinggi dan skor $<70$ : menunjukkan fungsi yang rendah (Tabel 2). ${ }^{8}$ 
Tabel 1. Domain Personal and Social Performance Scale (PSP)

\begin{tabular}{ll}
\hline Ranah Penilaian & Komponen \\
\hline Perawatan Diri & Minum Obat \\
Makan & Mandi \\
Keramas & Menyikat Gigi \\
& Mengganti Pakaian \\
\hline Aktivitas yang berguna secara sosial & Bekerja atau bersekolah \\
& Bekerja sebagai relawan atau mengikuti aktivitas \\
Hubungan personal dan sosial & kelompok \\
& Melakukan pekerjaan rumah tangga \\
\hline Perilaku mengganggu dan agresif & Hubungan dengan pasangan, keluarga dan atau teman- \\
& teman \\
Sistem pendukung di luar terapi \\
\hline Bicara terlalu keras dan menyumpah \\
Mengancam melukai diri sendiri atau orang lain \\
Memecahkan atau melempar benda-benda \\
\hline
\end{tabular}

\section{Tabel 2. Interval penilaian Skala PSP}

\begin{tabular}{|c|c|}
\hline Nilai & Kategori \\
\hline $100-91$ & $\begin{array}{l}\text { Fungsi yang sangat baik pada semua ranah. Pasien dipertimbangkandalam } \\
\text { kualitas yang baik, mampu beradaptasi terhadap masalah } \\
\text { kehidupan dengan adekuat, dan terlibat dalam aktivitas dan } \\
\text { ketertarikan yang luas. }\end{array}$ \\
\hline $90-81$ & $\begin{array}{l}\text { Fungsi yang baik pada semua ranah. Pasien hanya menunjukkan } \\
\text { masalah kesulitan yang umum. }\end{array}$ \\
\hline $80-71$ & Kesulitan ringan pada satu atau lebih dari ranah a-c \\
\hline $70-61$ & $\begin{array}{l}\text { Kesulitan terlihat tapi tidak sampai nyata/jelas pada satu atau lebih ranah a-c; atau } \\
\text { kesulitan } \quad \text { ringan } \quad \text { pada d. }\end{array}$ \\
\hline $60-51$ & $\begin{array}{l}\text { Kesulitan yang nyata/jelas hanya pada salah satu ranah a-c; atau } \\
\text { adanya kesulitan yang terlihat pada ranah d }\end{array}$ \\
\hline $50-41$ & $\begin{array}{l}\text { Kesulitan yang nyata/jelas pada dua atau tiga ranah a-c; atau kesulitan berat hanya } \\
\text { pada satu domain a-c tanpa kesulitan yang nyata/jelas pada dua ranah lainnya. Tidak } \\
\text { ada kesulitan yang nyata/jelas pada d. }\end{array}$ \\
\hline $40-31$ & $\begin{array}{l}\text { Kesulitan berat hanya pada satu dari ranah a-c dan kesulitan yangnyata/jelas } \\
\text { pada paling tidak satu dari dua yang lainnya; atau } \\
\text { kesulitan yang nyata/jelas pada ranah d. }\end{array}$ \\
\hline $30-21$ & $\begin{array}{l}\text { Kesulitan berat pada dua ranah a-c; atau kesulitan pada d, walaupun } \\
\text { jika kesulitan berat dan nyata/jelas tidak ada pada ranah a-c. }\end{array}$ \\
\hline $20-11$ & $\begin{array}{l}\text { Kesulitan berat pada semua ranah a-c; atau kesulitan sangat beratpada d, walaupun } \\
\text { kesulitan berat tidak ada pada ranah a-c. Jika pasien beraksi terhadap stimulus } \\
\text { eksternal, skor yang disarankan (20-16);jika tidak (16-11) }\end{array}$ \\
\hline $10-1$ & $\begin{array}{l}\text { Tidak adanya otonomi pada fungsi dasar dengan perilaku yang ekstrim tetapi tanpa } \\
\text { risiko pertahanan hidup (skor 10-6); atau dengan risiko pertahanan hidup, seperti } \\
\text { malnutrisi, dehidrasi, infeksi, tidak } \\
\text { dapat menyadari situasi berbahaya (skor 5-1) }\end{array}$ \\
\hline
\end{tabular}

Prosedur penelitian meliputi pasien skizofrenia yang diberikan consent menjadi subjek penelitian oleh keluarganya dinilai fungsi sosial dan personal dengan skor PSP di IGD dengan sumber alloanamnesa keluarga. Subjek dibagi secara acak menjadi 2 kelompok, perlakuan dan kontrol. Kelompok perlakuan diberikan ajuvan tablet asam folat $2 \mathrm{mg} /$ hari selama 4 minggu dan anti psikotik 
standar. ${ }^{9}$ Kelompok kontrol diberikan Kelompok kontrol diberikan placebo berupa kapsul saccharin lactis selama 4 minggu dan anti psikotik. Efek samping terkait ajuvan serta kondisi klinis pasien secara umum misalnya menjadi gelisah, muncul kondisi kegawatan (sindroma neuroleptik maligna) dievaluasi oleh peneliti setiap hari. Subjek dimonitor dan dievaluasi terkait efek samping ajuvan dan kondisi klinis setiap hari. Monitoring pemberian ajuvan dengan menggunakan kartu pemberian obat, dilakukan wawancara kepada pasien dan dikonfirmasi ke petugas medis yang memberikan ajuvan. Pada minggu keempat subjek penelitian dinilai fungsi sosial dan personalnya dengan sumber alloanamnesa perawat di ruang subjek dirawat sebelum pulang. Penelitian telah diajukan dan dinyatakan lulus etik oleh Komite Etik Penelitian Kesehatan (KEPK) RSJD dr. Amino Gondohutomo dengan SK No 420/6043 tanggal 26 Juni 2020. Analisis data menggunakan uji analisis Mann Whitney.

\section{HASIL}

Didapatkan 66 subjek pasien skizofrenia kronik yang memenuhi kriteria inklusi. Dari jumlah tersebut, 2 subjek diantaranya Drop Out karena kejang dan Sindrom Neuroleptik Maligna. Tidak dijumpai adanya efek samping obat selama intervensi sehingga saat akhir penelitian jumlah subjek pada kelompok perlakuan dan kontrol masing-masing tetap 32 orang.

\section{Analisis Karakteristik Demografi}

Pada karakteristik demografi subjek penelitian didapatkan bahwa tidak ada perbedaan yang bermakna diantara variabel - variabel demografi (Tabel 3). Pada penelitian ini diteliti mengenai variabel demografi meliputi jenis kelamin, usia, tingkat pendidikan, status pernikahan, status pekerjaan dan ada tidaknya faktor genetik dalam keluarga. Tidak ada perbedaan pada variabel demografi yang diteliti di kedua kelompok. Pada variabel jenis kelamin didapatkan pada kelompok perlakuan sebesar 71,9\% subjek laki - laki, sedang pada kelompok kontrol didapatkan 65,6\% (p $=0.590$ ). Rerata umur subjek penelitian pada kelompok perlakuan adalah $34,75 \pm 8,45$ tahun, kelompok kontrol 34,41 $\pm 8,64$ tahun $(\mathrm{p}=0,873)$. Variabel status pernikahan pada kelompok perlakuan sebanyak 53,1\% subjek belum menikah, sedangkan kelompok kontrol 50\% sudah menikah (p $=0,240)$. Pada variabel pendidikan, didapatkan kelompok perlakuan sebesar 40,6\% lulus SMA sedangkan kelompok kontrol 50\% lulus pendidikan SMP $(\mathrm{p}=0,117)$. Pada variabel pekerjaan, didapatkan pada kelompok perlakuan $(53,1 \%)$ maupun kelompok kontrol $(62,5 \%)$ subjek yang bekerja $(\mathrm{p}=0,440)$. Pada variabel genetik skizofrenia dalam keluarga didapatkan kelompok perlakuan dan kelompok kontrol masing - masing $12,5 \%$ terdapat riwayat genetik dalam keluarga $(\mathrm{p}=$ $1)$.

Tabel 3. Deskriptif Karakteristik Demografi Subjek Penelitian.

\begin{tabular}{|c|c|c|c|c|}
\hline \multirow{2}{*}{ Variabel } & \multicolumn{2}{|c|}{ Kelompok } & \multirow{2}{*}{ Total } & \multirow{2}{*}{$p$} \\
\hline & Kontrol & Perlakuan & & \\
\hline \multicolumn{5}{|l|}{ Jenis kelamin } \\
\hline Laki-laki & $21(65,6 \%)$ & $23(71,9 \%)$ & $44(68,8 \%)$ & $0,590^{¥}$ \\
\hline Perempuan & $11(34,4 \%)$ & $9(28,1 \%)$ & $20(31,3 \%)$ & \\
\hline Umur & $34,41 \pm 8,64$ & $34,75 \pm 8,45$ & $34,58 \pm 8,48$ & $0,873^{\S}$ \\
\hline \multicolumn{5}{|l|}{ Status perkawinan } \\
\hline Menikah & $16(50 \%)$ & $10(31,3 \%)$ & $26(40,6 \%)$ & $0,240^{\ddagger}$ \\
\hline Belum menikah & $13(40,6 \%)$ & $17(53,1 \%)$ & $30(46,9 \%)$ & \\
\hline Cerai mati & $1(3,1 \%)$ & $0(0 \%)$ & $1(1,6 \%)$ & \\
\hline Cerai hidup & $2(6,3 \%)$ & $5(15,6 \%)$ & $7(10,9 \%)$ & \\
\hline \multicolumn{5}{|l|}{ Pendidikan } \\
\hline SD & $2(6,3 \%)$ & $8(25 \%)$ & $10(15,6 \%)$ & $0,117^{¥}$ \\
\hline SMP & $16(50 \%)$ & $9(28,1 \%)$ & $25(39,1 \%)$ & \\
\hline SMA/K & $13(40,6 \%)$ & $13(40,6 \%)$ & $26(40,6 \%)$ & \\
\hline $\mathrm{S} 1$ & $1(3,1 \%)$ & $2(6,3 \%)$ & $3(4,7 \%)$ & \\
\hline \multicolumn{5}{|l|}{ Pekerjaan } \\
\hline Bekerja & $20(62,5 \%)$ & $17(53,1 \%)$ & $37(57,8 \%)$ & $0,448^{\ddagger}$ \\
\hline Tidak bekerja & $12(37,5 \%)$ & $15(46,9 \%)$ & $27(42,2 \%)$ & \\
\hline \multicolumn{5}{|l|}{ Genetik } \\
\hline Ada & $4(12,5 \%)$ & $4(12,5 \%)$ & $8(12,5 \%)$ & $1,000^{¥}$ \\
\hline Tidak & $28(87,5 \%)$ & $28(87,5 \%)$ & $56(87,5 \%)$ & \\
\hline
\end{tabular}

Keterangan : ${ }^{\S}$ Independent $\mathrm{t} ;{ }^{¥}$ Chi square 
Analisis Skor Personal And Social Performance Kelompok Perlakuan dan Kelompok Kontrol.

Tabel 4. Distribusi skor Personal and Social Performance Scale pre test kelompok kontrol dan kelompok perlakuan.

\begin{tabular}{cccccccc}
\hline Skala PSP & $0-10$ & $11-20$ & $21-30$ & $31-40$ & $41-50$ & $51-60$ & Total \\
\hline Kontrol & & & & & & & \\
n & 0 & 9 & 6 & 13 & 4 & 0 & 32 \\
$\%$ & 0 & 28,1 & 18,8 & 40,6 & 12,5 & 0 & 100 \\
$\begin{array}{c}\text { Perlakuan } \\
\text { n }\end{array}$ & 0 & 11 & 8 & 5 & 6 & 2 & 32 \\
$\%$ & 0 & 34,4 & 25 & 15,6 & 18,8 & 6,2 & 100 \\
\hline
\end{tabular}

Tabel 5. Distribusi skor Personal and Social Performance Scale post test kelompok kontrol dan kelompok

\begin{tabular}{cccccccc}
\multicolumn{7}{c}{ perlakuan } \\
\hline Skala PSP & $41-50$ & $51-60$ & $61-70$ & $71-80$ & $81-90$ & $91-100$ & Total \\
\hline Kontrol & 1 & 3 & 15 & 9 & 4 & 0 & 32 \\
$\mathrm{n}$ & 3,1 & 9,4 & 46,9 & 28,1 & 12,5 & 0 & 100 \\
$\%$ & & & & & & & \\
Perlakuan & 2 & 5 & 11 & 8 & 6 & 0 & 32 \\
$\mathrm{n}$ & 6,2 & 15,6 & 34,4 & 25 & 18,8 & 0 & 100 \\
$\%$ & &
\end{tabular}

Skor PSP kelompok perlakuan meningkat dibandingkan antara pre dan post test dan bermakna secara statistik $(\mathrm{p}<0,001)$. Demikian juga skor PSP kelompok kontrol meningkat dibandingkan antara pre dan post test dan juga bermakna secara statistik ( $\mathrm{p}<0,001)$. Selisih (delta) skor PSP kelompok perlakuan lebih tinggi dibanding kelompok kontrol $(\mathrm{p}=0,029)($ Tabel 6).

Tabel 6. Perbedaan Skor Personal and Social Performance Scale Pre Test, Post Test Dan Delta Kelompok Perlakuan Dan Kelompok Kontrol.

\begin{tabular}{cccc}
\hline \multirow{2}{*}{ PSP } & \multicolumn{2}{c}{ Kelompok } & \multirow{2}{*}{$p$} \\
\cline { 2 - 3 } & Kontrol & Perlakuan & $0,849^{\mathrm{b}}$ \\
Pre test & $29,50 \pm 10,45$ & $29,50 \pm 13,15$ & $0,008^{\mathrm{b} *}$ \\
Post test & $68,50 \pm 9,84$ & $76,27 \pm 10,06$ & \\
\hline$p$ & $<0,001^{\mathrm{c} *}$ & $<0,001^{\mathrm{c} *}$ & $0,029^{\mathrm{a} *}$ \\
\hline Delta & $39,00 \pm 11,63$ & $46,77 \pm 15,02$ & \\
\hline
\end{tabular}

Keterangan : * Signifikan $(\mathrm{p}<0,05) ;{ }^{\mathrm{a}}$ Independent $\mathrm{t} ;{ }^{\mathrm{b}}$ Mann whitney; ${ }^{\mathrm{c}}$ Wilcoxon

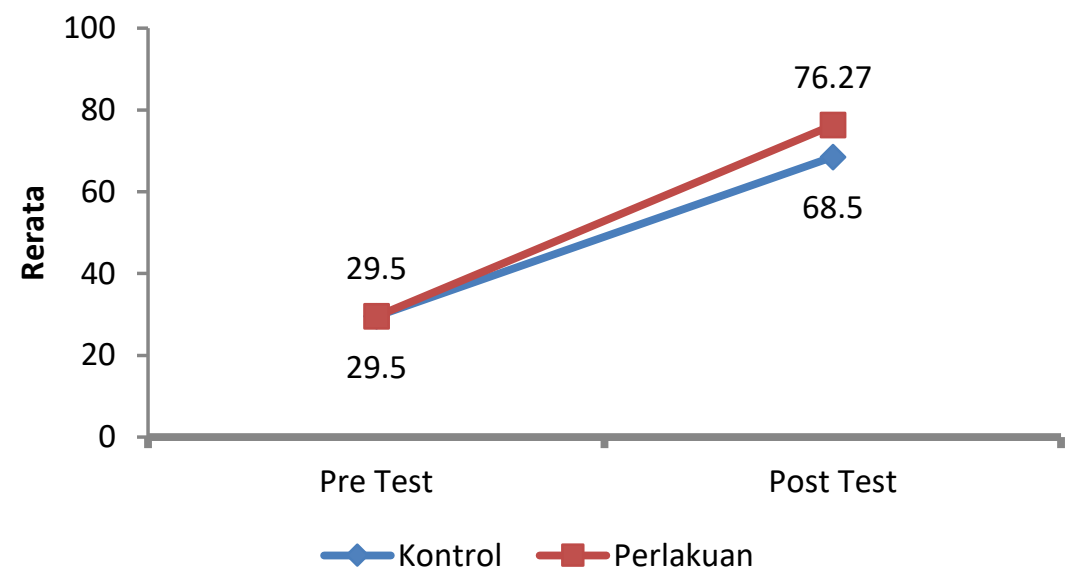

Gambar 1. Perubahan Skor PSP Dari Pre Test Dan Post Test Kelompok Perlakuan dan kelompok kontrol $(\mathbf{n}=64)$.

Gambar 1 memperlihatkan adanya perubahan skor PSP saat pre dan post test pada kedua kelompok. Dapat dilihat pada saat pre test rerata skor
PSP kedua kelompok sebesar 29,5 sedangkan pada saat post test rerata skor PSP kelompok perlakuan sebesar 76,27 sedangkan pada kelompok kontrol 68,5 . 


\section{PEMBAHASAN}

Hasil penelitian menunjukkan adanya perbedaan fungsi sosial pasien dengan skizofrenia kronik yang mendapat penambahan asam folat dan yang hanya mendapat anti psikotik, yang dinilai berdasarkan skor PSP.

\section{Gambaran Karakteristik Demografi Subjek Penelitian}

Subjek di kedua kelompok tidak berbeda bermakna pada variabel jenis kelamin, usia, status pernikahan, status pekerjaan, tingkat pendidikan dan riwayat genetik (tabel 1). Subjek laki - laki $(68,8 \%)$ lebih banyak dibanding perempuan, dengan rerata usia 34,58 $\pm 8,48$ tahun. Hal ini sesuai dengan studi epidemiologi usia puncak skizofrenia antara 30 - 40 tahun, baik pada laki dan perempuan. ${ }^{10}$

Pada variabel status pernikahan, kelompok perlakuan $53,1 \%$ belum menikah sedang pada kelompok kontrol 50\% subjek sudah menikah. Hal ini berbeda dengan temuan Naheed dkk (2012) di India yang menyebutkan bahwa pasien skizofrenia yang menikah mempunyai fungsi sosial yang lebih baik dibanding yang tidak menikah. Pernikahan memungkinkan pasien mendapat dukungan mental dari pasangan untuk menjalani kehidupan normal mereka. ${ }^{11}$

Pada variabel pendidikan, kelompok perlakuan 40,6\% subjek lulus SMA, sedang kelompok kontrol 50\% subjek lulus SMP. Perbedaan tingkat pendidikan tidak bermakna dalam penelitian ini. Hal ini berbeda dengan temuan Lystad et al (2016) dan penelitian di Yordania yang menyatakan bahwa tingkat pendidikan yang rendah dan tidak menikah merupakan faktor demografi yang berkontribusi pada fungsi sosial yang buruk pada skizofrenia. ${ }^{2,12}$

Pada variabel pekerjaan, di kedua kelompok mayoritas subjek bekerja, di kelompok perlakuan $53,1 \%$ dan kelompok kontrol 62,5\% bekerja. Penelitian lain menunjukkan subjek yang tidak bekerja mempunyai fungsi sosial yang lebih buruk dari individu yang bekerja. Ketidakstabilan perumahan dan keuangan, pada gilirannya membuat akses perawatan dan pengobatan menjadi lebih sulit, menyebabkan kekambuhan gejala dan rawat inap periodik untuk stabilisasi fase akut. ${ }^{13,14}$ Sedangkan pada variabel genetik, di kedua kelompok sebesar $12,5 \%$ terdapat riwayat genetik gangguan jiwa dalam keluarga. Pada kedua variabel ini baik kelompok perlakuan maupun kontrol mempunyai kondisi yang hampir sama.

Pada individu skizofrenia yang tidak bekerja, belum menikah dan berpendidikan rendah cenderung berfungsi rendah atau lebih buruk. Lehman dalam studinya mengungkapkan bahwa individu yang menikah memiliki kualitas hidup yang lebih baik daripada mereka yang belum menikah. Berkenaan dengan pendidikan, penelitian memperlihatkan kualitas kehidupan yang lebih rendah pada pasien skizofrenia yang memiliki tingkat pendidikan lebih tinggi. ${ }^{15}$

Penelitian - penelitian yang ada menunjukkan fungsi personal dan sosial yang lebih baik pada pasien yang mendapat dukungan keluarga, pada mereka yang bekerja, pada mereka yang tidak memiliki gangguan mental pada anggota keluarga lainnya dan pada pasien yang menjalani perawatan di rumah sakit dibandingkan dengan pasien yang menerima perawatan rawat jalan. Kombinasi terapi psikososial rumah sakit dengan terapi antipsikotik yang teratur, dukungan keluarga dan sosial membantu dalam reintegrasi dan resosialisasi yang lebih cepat dan kualitas hidup yang lebih baik pada pasien skizofrenia. ${ }^{15}$

Namun penelitian tentang faktor sosiodemografi yang berpengaruh pada fungsi sosial pasien skizofrenia menunjukkan hasil yang beragam. Penelitian Coskun (2018) menyatakan tidak ada perbedaan fungsi sosial secara umum untuk faktor usia, jenis kelamin dan status pernikahan. Penelitian lain menyebutkan bahwa wanita mempunyai fungsi sosial yang lebih tinggi dibanding laki - laki. ${ }^{14}$ Penelitian penulis menunjukkan bahwa faktor demografi usia, jenis kelamin, tingkat pendidikan, status pernikahan, status pekerjaan dan riwayat genetik tidak bermakna untuk membedakan tingkat fungsi sosial subjek skizofrenia yang diteliti.

Perbedaan hasil ini mungkin disebabkan oleh faktor geografis, budaya dan tingkat sosial ekonomi populasi yang diteliti sehingga berpengaruh pada luaran psikososial jangka panjang individu dengan skizofrenia. Sebagaimana penelitian Naheed dkk (2012) tentang faktor - faktor yang berpengaruh pada fungsi sosial pasien skizofrenia di negara maju dan negara berkembang. Naheed menyebutkan bahwa faktor usia, jenis kelamin, pekerjaan, pendidikan, pernikahan, beban keluarga, dukungan keluarga dan masyarakat, kepatuhan pengobatan, lama sakit yang tidak diobati serta mitos penyakit menunjukkan pengaruh yang beragam terhadap fungsi sosial pada penelitian di beberapa negara maju dan negara berkembang. Namun pada penelitian ini, penulis tidak dipertimbangkan tentang DUP (Duration Untreated Psychosis), hal ini merupakan salah satu kelemahan penelitian. ${ }^{11}$

\section{Perbedaan Skor PSP Kelompok Perlakuan Dan Kelompok Kontrol.}

Rerata skor skala PSP post test kelompok perlakuan 76,27 $\pm 10,06$ sedangkan kelompok kontrol 68,50 \pm 9,84. Purnama dkk (2008) menyatakan skor PSP $\geq 70$ menunjukkan fungsi 
personal dan sosial yang tinggi, sedangkan skor $<70$ menunjukkan fungsi personal dan sosial yang rendah. Skor skala PSP antara 60 - 70 menunjukkan adanya kesulitan terlihat tapi tidak sampai nyata / jelas pada satu atau lebih ranah perawatan diri, aktivitas sosial yang berguna dan hubungan sosial dan personal atau kesulitan ringan pada perilaku agresif dan permusuhan. Sedangkan skor skala PSP antara 71 - 80 menunjukkan adanya kesulitan ringan pada satu atau lebih pada ranah perawatan diri, aktivitas sosial yang berguna dan hubungan sosial dan personal.

Pada pre test didapatkan subjek kelompok perlakuan $34.35 \%$ pada skor $11-20$ sedang pada kelompok kontrol 40,6\% pada skor 31- 40. Hal ini menunjukkan fungsi personal dan sosial kelompok perlakuan base line (pre test) lebih rendah dibanding kontrol. Pada post test subjek kelompok perlakuan mengalami perbaikan fungsi personal dan sosial (skor PSP > 70) sebesar 43,7\% sedang kelompok kontrol sebesar 40,6\%. Hal ini menunjukkan lebih banyak subjek yang mengalami perbaikan fungsi personal dan sosial pada kelompok perlakuan dibanding kontrol.

Setelah pemberian ajuvan asam folat selama 4 minggu, pada kelompok perlakuan terdapat 5 subjek yang masih terlihat mengalami hendaya pada aktivitas yang berguna, sedangkan pada domain tersebut terdapat 8 subjek di kelompok kontrol. Perbaikan fungsi ini terkait dengan peran asam folat yang memperbaiki stres oksidatif pada penyakit skizofrenia kronis. Hal ini sejalan dengan penelitian Damanik di Sumatera Utara (2017) yang meneliti perbaikan skor PSP pada pasien skizofrenia laki laki yang dirawat, dibandingkan antara yang mendapat anti psikotik risperidon saja dan yang mendapat risperidon dan asam folat. Namun suplementasi asam folat ini belum dapat menunjukkan domain - domain fungsi personal dan sosial mana saja yang membaik. Hal ini dikarenakan banyak faktor yang berpengaruh pada perbaikan fungsi sosial, misalnya faktor lingkungan, peran care giver serta kronisitas penyakit subjek itu sendiri.

Keterbatasan penelitian ini diantaranya tidak menilai fungsi kognitif dan gejala negatif pasien yang sangat berpengaruh dengan fungsi personal dan sosial pasien. Subjek penelitian ini juga kurang homogen, yaitu dalam hal kronisitas penyakit dan perbedaan sumber data penilaian fungsi sosial pre dan post test. Faktor kronisitas / lama sakit, subjek penelitian beragam dari 2 tahun hingga lebih dari 10 tahun. Semakin kronis penyakit, tingkat stres oksidatif makin berat sehingga efek antioksidan menjadi kurang optimal serta membutuhkan pemberian dalam waktu yang lebih lama. Frekuensi hospitalisasi (rawat inap di RS), sangat berpengaruh pada fungsi sosial pasien sebelum intervensi. Perjalanan skizofrenia yang kronik progresif seringkali sebanding dengan penurunan fungsi sosial pasien. Penilaian fungsi personal dan sosial pre test dilakukan di IGD melalui wawancara care giver (keluarga) pasien sedangkan penilaian post test dilakukan dengan wawancara paramedis di ruang stabil subjek dirawat sebelum pulang. Penulis mencoba meminimalkan perbedaan penilaian tersebut dengan sumber wawancara yang membersamai pasien minimal 8 jam per hari selama 2 minggu terakhir.

\section{SIMPULAN}

Terdapat manfaat pemberian ajuvan asam folat dalam memperbaiki fungsi personal dan sosial pasien skizofrenia kronis. Karakteristik demografi pasien skizofrenia kronis yang dirawat di RSJD dr. Amino Gondohutomo Semarang berdasarkan jenis kelamin, usia, status pernikahan, pendidikan, pekerjaan dan riwayat genetik, tidak berbeda secara statistik. Kelompok asam folat maupun plasebo mengalami peningkatan skor Personal and Social Performance sebelum dan sesudah intervensi. Peningkatan skor Personal and Social Performance lebih besar pada kelompok asam folat. Perlu dipertimbangkan pemberian ajuvan asam folat pada tatalaksana pasien skizofrenia kronis sehingga perbaikan fungsi personal dan sosial dapat tercapai.

\section{UCAPAN TERIMA KASIH}

Terimakasih kepada direktur dan segenap civitas hospitalia RSJD. Dr. Amino Gondohutomo Semarang yang telah memberikan kesempatan melakukan penelitian ini.

\section{DAFTAR PUSTAKA}

1. Howes OD, Fusar-Poli P, Bloomfield M, Selvaraj S, McGuire P. From the prodrome to chronic schizophrenia: The neurobiology underlying psychotic symptoms and cognitive impairments. Curr Pharm Dess. 2012;18(4):459-65.

2. Gonzalez-blanco L, Garcia-portilla MP, Dal Santo F, Garcia-Alvarez L, de la Fuente-Tomas L, Menendez-Miranda I et al. Predicting realworld functioning in outpatients with schizophrenia: Role of inflammation and psychopathology. Psychiatry Res. 2019; 280: 112509.

3. Wang D, Zhai J, Liu D. Serum folate levels in Schizophrenia: A meta-analysis. Psychiatry Res. 2016; 235: 83-9.

4. Badan Penelitian dan Pengembangan Kesehatan. RISKESDAS 2018. Jakarta: Kemenkes RI. 2018 
5. El Mawella SMA, Hussein HA, Ahmed T. Folate, Vitamin B12, and negative symptoms in schizophrenia. Egypt J Psychiatr. 2018;39: 8994.

6. Zugno AI, Canever L, Heylmann AS, Wessler PG, Steckert A, Mastella GA, et al. Effect of folic acid on oxidative stress and behavioral changes in the animal model of schizophrenia induced by ketamine. J Psychiatr Res. 2016;81:23-35.

7. Wójciak P, Remlinger-Molenda A, Rybakowski J. Stages of the clinical course of schizophrenia (staging concept). Psychiatr Pol. 2016;50(4):717-30.

8. Damanik R. Korelasi Antara Fungsi Sosial dan Personal dan Fungsi Kognitif pada Penderita Skizofrenia Laki-Laki di Instalasi Rawat Inap Rumah Sakit jiwa Prof. dr. Muhammad Ildrem Medan. Medan. Universitas Sumatera Utara. Thesis. 2017.

9. Roffman JL, Lamberti JS, Achtyes E, Macklin EA, Galendez GC, Raeke LH, et al. Randomized multicenter investigation of folate plus vitamin B12 supplementation in schizophrenia. JAMA Psychiatry. 2013;70(5):481-9.

10. Charlson FJ, Ferrari AJ, Santomauro DF, Diminic S, Stockings E, Scott JG, et al. Global epidemiology and burden of schizophrenia: Findings from the global burden of disease study 2016. Schizophr Bull. 2018;44(6):1195203.

11. Naheed M, Akter KA, Tabassum F, Mawla R, Rahman M. Factors contributing the outcome of Schizophrenia in developing and developed countries : A brief review. Int Curr Pharm J. 1970;1(4):81-5.

12. Desalegn D, Girma S, Abdeta T. Quality of life and its association with psychiatric symptoms and socio-demographic characteristics among people with schizophrenia: A hospital-based cross-sectional study. PLoS One. 2020;15(2):115.

13. Harvey PD, Strassnig MT, Silberstein J. Prediction of disability in schizophrenia: Symptoms, cognition, and self-assessment. J Exp Psychopathol. 2019;10(3): 1-20.

14. Kaya Y. Global Social Functioning of Patients with Schizophrenia and Care Burden of Caregiving Relatives. J Psychiatr Nurs. 2018;10(1):28-38.

15. Arsova Hadzi-Angelkovska S. PejoskaGerazova V. Novotni A. Isjanovski V. Personal And Social Functioning In Patients With Schizophrenia. Contributions Sec Biol Med Sci. 2010; XXXI(2):: 209-221. 